\title{
SYNTHETIC MEASUREMENT USED AS ASSESSMENT OF SPATIAL DISPARITIES OF THE NATURAL ENVIRONMENT
}

\author{
WYKORZYSTANIE MIARY SYNTETYCZNEJ DO ROZPOZNANIA \\ PRZESTRZENNYCH DYSPROPORCJI ŚRODOWISKA NATURALNEGO
}

https://doi.org/10.34739/zn.2019.49.10

\author{
Jarosław Wenancjusz Przybytniowski ${ }^{1}$, Paweł Dziekański² \\ 1 Poland, The Jan Kochanowski University in Kielce, Institute of Management \\ ORCID: 0000-0001-6164-2953 e-mail: j.w.przybytniowski@wp.pl \\ 2 Poland, The Jan Kochanowski University in Kielce, Institute of Management \\ ORCID: 0000-0003-4065-0043, e- mail: pdziekan@interia.eu
}

\begin{abstract}
One of important factors of attractiveness of a region is its natural environment, namely a set of natural elements which are of interest to a tourist. In terms of economy, it is a source of raw materials and energy, it ensures geographical space, business opportunities and a place to live and relax. The aim of the research included in this article is to indicate the possibility of using synthetic measurement to recognize spatial disparities of the natural environment on the basis of selected diagnostic features of 102 municipalities of the Świętokrzyskie Voivodeship. The data presented in this article refer to 2009, 2012 and 2015 and come from the Local Data Bank. The following variables were selected: the total use of household water per one inhabitant, the distribution network per $100 \mathrm{~km}^{2}$ - water pipe system, the distribution network per $100 \mathrm{~km}^{2}$ - sewage system, woodland area, areas protected by law, protected monuments. The elements indicated refer to entities which function and operate in a territorial unit. The methods presented enable us to identify areas of human life (or human impact on the environment) of higher/lower efficiency (which depends on the level of synthetic measure) and, then, programme their support from public funds within the framework of the regional policy.

Keywords: ecological awareness, synthetic measures, service quality, natural environment
\end{abstract}

\begin{abstract}
Streszczenie: Celem badań w artykule było wskazanie możliwości wykorzystania miary syntetycznej do rozpoznania przestrzennych dysproporcji środowiska naturalnego na podstawie wybranych cech diagnostycznych 102 gmin województwa świętokrzyskiego, jako obszaru peryferyjnego. Dane zaprezentowane w opracowaniu dotyczą lat 2009, 2012 i 2015 i pochodzą z Banku Danych Lokalnych. W oparciu o tak postawiony cel badawczy została sformułowana hipoteza, iż zastosowanie właściwych miar syntetycznych dała możliwość rozpoznania przestrzennych dysproporcji zachodzących w środowisku naturalnym. Do oceny środowiska naturalnego zostały wybrane następujące zmienne: zużycie wody w gospodarstwach domowych ogółem na 1 mieszkańca, sieć rozdzielcza na $100 \mathrm{~km}^{2}$ sieć wodociągowa, sieć rozdzielcza na $100 \mathrm{~km}^{2}$ sieć kanalizacyjna, powierzchnia gruntów leśnych, obszary prawnie chronione, pomniki chronione. W oparciu o przeprowadzone badania można stwierdzić, iż: przedstawione metody umożliwiają identyfikację obszarów o wyższym/niższym poziomie efektywności działania, a następnie programowanie ich wsparcia ze środków publicznych w ramach polityki regionalnej.
\end{abstract}

Słowa kluczowe: świadomość ekologiczna, miary syntetyczne, jakość usługi, środowisko naturalne

\section{Introduction}

Numerous studies have dealt with the benefits of natural ecosystems and in recent years even more so with ecosystem services, as well as interactions of ecosystem services with each other and with the urban and peri-urban environment. This paper suggests an approach to the spatial unity of the Świętokrzyskie region using basic ecosystem services identified by land use. The aim was, first, to describe the spatial distribution of basic ecosystem services and their interactions and, second, to investigate whether they form important statistical correlations with the basic features. (Kalfas, Zagkas, Raptis, Zagkas, 2019). The list of fundamental and key terms characterising the development trend of modern civilisation in the period of ever-changing surroundings might include two concepts: awareness and ecology. The collation of these two concepts is even more 
Przybytniowski J.W., Dziekański P., SYNTHETIC MEASUREMENT USED AS ASSESSMENT OF SPATIAL DISPARITIES OF THE NATURAL ENVIRONMENT, Zeszyty Naukowe Uniwersytetu Przyrodniczo-Humanistycznego w Siedlcach Nr 122, Seria: Administracja i Zarządzanie (49) 2019

interesting as they are aimed at two, seemingly different environments, in which live and function intelligent beings, i.e., humans: the internal environment - the higher states of mind, and the external environment: physical and biological space. Here, we can risk claiming that the measure of sustainable development is the growing conviction that both these environments are strongly related. Thus, it is certainly easier for us to see the Earth without people than people without the Earth. It should be remembered that human business activity, despite the best security measures, creates the risk of damage to the natural environment. Economic entities potentially hazardous to the environment are, and will be, facing the threat of high costs of restoring the environment to its original form.

In the presented study the global perspective is limited to the description of the possibilities of using synthetic measurement to study spatial disparities of the natural environment on the basis of selected diagnostic features of 102 municipalities ${ }^{1}$ of the Świętokrzyskie Voivideship as a peripheral area. The data presented in the study refer to the years 2009, 2012 and 2015 and come from the Local Data Bank. The 2015 border date results from the closing stage of the research carried out by the authors. This study is an introduction to deeper research that will cover the following years, as well as additional regions of Eastern Poland. The indicated division into 4 quartile groups of units statistically similar to each other was made on the basis of the value of quartile 1,2 and 3. The analysis shows that the most strongly affecting the natural environment are group $A$ units, and the least group $D$, with the assumption indicating variables influencing them.

The answers sought to make a research problem correspond to the research conducted by the authors. The aim of the research was also an intention to indicate the direction in educational processes which may appear effective in creating pro-ecological attitudes. The results of the studies and analyses presented here, should bring the knowledge growth, as well as ecological awareness increase, to the inhabitants of Świętokrzyskie Voivodeship; the studies conducted in recent years show the level of ideas and social responsibility for the natural environment of both the voivodeship authorities and the inhabitants of the voivodeship.

\footnotetext{
${ }^{1}$ The 1999 administrative division in Poland consists of three tiers: voivodeship, county, commune.
}

\section{Literature review}

The environment is a natural barrier to economic growth. However, the quantitative increase of this capital has its defined borders and may last as long as a given country reaches a maximum level of social prosperity. It depends on the amount of available natural resources, soil quality, and climate type (Borys, 2013). Bearing in mind the determinants of environmental competitiveness of regions, their categorisation must be mentioned: natural conditions, soil and farming systems, state and degree of water pollution, quality and level of atmospheric air pollution, level and structure of produced waste, areas and objects of special natural value, level of industrial and road noise and the infrastructure of environmental protection and water management. Other elements which make it possible to assess environmental competitiveness refer to the function and operation of territorial selfgovernment units (Kasztelan, 2010). It must also be remembered that it is difficult to evaluate the environmental competitiveness of counties. It requires taking into account many other variables the selection of which may have an important impact on the results acquired and on the possibility of using the method to assess regions of various countries (Dziekański, 2015).

Environmental education, as explained by J.H., Jr. Ward, (1963; Stanny, 2012; Kiselitsa; Shilova; Liman; Naumenko, 2018), means shaping the full picture of the relationship between nature, the human being and society, where the interrelations between man and the environment are presented. Simultaneously, it teaches responsibility for all the changes which are made in the natural environment.

In Poland the research considered as pioneer, as well as the most complex, devoted to the awareness of the natural environment, was the research conducted in the Tarnobrzeg region in 1983 (Tarnobrzeg voivodship (old division of voivodships, Frączak, 2001), where it was concluded that people concentrate more on acting in the situations that threaten people directly, e.g., if drinking water is contaminated in a defined place, rather than on "remote" threats, e.g., the threat to the forests in danger of pest or clearing, of which the consequence is climate change. Moreover, it was found that people treat the natural environment as a value, however, they do not feel any need for acting on its behalf. In scientific discourse, 
environmental awareness is defined as a form of social awareness which is reflected in thoughts and experiences of individual people, as well as in socially accepted norms connected with understanding and valuating the environment (Dąbrowska, 2017). From the individual point of view, this awareness results from the socialisation process in which each of us has participated throughout our entire conscious lives. It is a subjective phenomenon, which means the mutual complementation of ecological knowledge and imagination (Sonowal, 2009; Przybytniowski, 2017), as well as safety connected with it, including financial security (Przybytniowski, 2017).

The development of human awareness and its formation, in the area of environmental protection, can be illustrated in three stages, as (Mikhaylov, 2018; Rook, 2013):

1. A common, informal one, where the attitude is based on verified opinions and information.

2. An ideological one, frequently encountered among activists of ecological movements and organizations.

3. A universal one, which refers to scientific attitude, based on the results achieved by knowledge and upbringing.

This notion can be defined in a much broader sense as the total of values and opinions about the environment and, in a narrower (more axiological) sense, as the state of knowledge, ideas and views of people about the role of the environment in the life of the society and as the knowledge about the instruments and means of managing, shaping and preserving the environment (SelivanovaFyodorova, Komarova, Lonska, Mietule, 2019; Strong, 1996; Houston, Bradham, 2008).

The possibility of using the natural environment for development requires proper quality of resources and appropriate attitudes of their users. Environmental competitive advantage of rural areas is the result of actions of all the entities operating in the areas. With regard to developing and maintaining the quality of the natural environment, also of the greatest importance is a prevailing group of residents, i.e., entrepreneurs, as well as the activity of local governments in the counties (Podel, 2015). One of the tasks of a local government is to undertake actions to facilitate the economic, environmental and social development of the county. Therefore, the tasks of the county in

\footnotetext{
${ }^{2}$ The division into stimulants and destimulants results from the Authors' experience. A variable is a stimulant if the higher the variable, the better the unit's demographic, social or economic situation; whereas a destimulant is when a variable increase
}

terms of environmental protection include, first of all, maintaining spatial order, water supply, sewage disposal, waste management, conservation of green areas. Also transport, health care, education, culture, public utilities have an impact on the environment and the quality of life of county residents. Hence, we can say that environmental management is a science and a practical activity connected with designing, implementing, controlling and coordinating environmental management processes. The processes of using, protecting and developing the environment take place in the social, economic and natural sphere (Toruński, 2012).

\section{Methodology and theoretical basis}

The aim of this study is to show the possibilities of applying a synthetic measurement to determine spatial disparity of the natural environment on the basis of selected diagnostic feature of 102 municipalities of the Świętokrzyskie Voivodeship as a peripheral area. The data presented in the study refer to the years 2009, 2012 and 2015 and come from the Local Data Bank.

In order to select variables for the evaluation of the natural environment, the authors used three criteria, i.e., substantial usefulness in evaluating a studied phenomenon, the degree of variability and the correlation of variables (Kukuła, 2014). The following variables were selected to assess the natural environment:

1) the total use of household water per 1 resident [cu m] D,

2) distribution network per $100 \mathrm{~km}^{2}$ - water pipe system $[\mathrm{km}] \mathrm{S}$,

3) distribution network per $100 \mathrm{~km}^{2}$ - sewage system $[\mathrm{km}] \mathrm{S}$,

4) woodland area [ha] $S$,

5) areas protected by law [ha] $S$,

6) protected monuments [pcs] $S$

7) nature monuments [pcs] S.

These variables directly or indirectly (due to human interference) influence the natural environment of the region. Depending on the impact of a variable on a studied phenomenon, the authors distinguished some stimulants (S) and destimulants $(D)^{2}$. The variables of low spatial variability (coefficient of variation below 0.10) and high variable correlation were removed from the further research process. According to the method of

reflects a decline in the level of a studied phenomenon, i.e., it shows the deterioration of the unit's demographic, social or economic situation. 
invertible matrix of correlation coefficients, diagonal elements (variables excessively correlated) of the values higher than 10 were eliminated from the set of variables (Wysocki, 1996).

In the next stage, the authors conducted the procedure of normalising diagnostic variables (of different names) using the zero unitarisation method, pursuant to the equation (1) and (2), i.e.,:

$$
z_{i j}=\frac{x_{i j}-\min _{i} x_{i}}{\max _{i} x_{i}-\min _{i} x_{i}}
$$

whereas the destimulant:

$$
z_{i j}=\frac{\max x_{i}-x_{i j}}{\max _{i} x_{i}-\min _{i} x_{i}}
$$

where:

$\mathrm{i}=1,2, \ldots \mathrm{N} ; \mathrm{j}=1,2, \ldots, \mathrm{p}$ ( $\mathrm{N}$ is a number of objects (the community),

$p-$ (number of features) - means the unitarised value of the feature for a studied unit,

$x_{i j}$ - means the value of $j^{\text {th }}$ feature for a studied unit, max - maximal value of $j^{\text {th }}$ feature, min - minimal value of $j^{\text {th }}$ feature (Tokarski, 2005).

Then, a synthetic measure was calculated based on the distance in the real space with the Euclidean metric, according to the formula:

$O E_{i t}=\sqrt{\frac{1}{p} \sum_{j=1}^{p}\left(1-z_{i j t}\right)^{2}}$

where:

$\mathrm{i}=1,2 \ldots \mathrm{N} ; \mathrm{j}=1,2 \ldots, \mathrm{p}$ ( $\mathrm{N}$ is the number of entities (county), $p-$ (number of features) - means the unitarised value of the feature for a studied unit,

$\mathrm{zij}$ - means the value of the $\mathrm{j}^{\text {th }}$ feature for a studied unit, max - maximal value of the $\mathrm{j}^{\text {th }}$ feature,

min - minimal value of the $j^{\text {th }}$ feature (Ginevičius, Gedvilaitè, \& Bruzgè, 2015; Trojak, Tokarski, 2013).

Synthetic measurement (3) allows measuring the distance brought to the range $[0 ; 1]$ in the real space with the Euclidean metric of the $i^{\text {th }}$ community in the year $t$ from a hypothetical model community. The value of this measurement equals 0 and means the maximal positive value of each of the studied stimulants whereas 1 means the weakest unit in the studied set (Collins, Scannell, 2005).

\section{Results and discussion}

The Świętokrzyskie Voivodeship is situated in the south-eastern part of Poland and belongs to the ecologically cleanest areas of Poland (Bury, Dziekański, 2013). The main industry of the Świętokrzyskie region are: steel industry (Ostrowiec Świętokrzyski, Ostrowiec County), metal industry (Skarżysko-Kamienna, Skarżysko County), machinery (Starachowice, Starachowice County), construction materials (Kielce, Kielce County), ceramics, foundry (Końskie, Końskie County), food processing (Pińczów, Pińczów County, Kielce). The economy of the Świetokrzyskie region is based on extractive industry in the area of construction materials (limestone, dolomites, marlstone, gypsum and sandstone), thanks to which the voivodeship is called the capital of Polish construction. The agricultural south is the back-up for ecological food production. The Świętokrzyskie Voivodeship is also a region of exceptional natural value (Table 1).

Table 1. Characteristics of selected areas (Counties) of the Świętokrzyskie Voivodeship

\begin{tabular}{ll}
\hline Counties & Characteristics \\
\hline Opatów & Agriculture, agrotourism, inductry (cement), dairy \\
Starachowice & Machinery and metal industry \\
Skarżysko & Metal industry, agriculture, commerce and services, construction \\
Busko & Agriculture (vegetables and orchards), agrotourism, heath resorts \\
Sandomierz & Agriculture (horticulture and orchards), agrotourism, industry (glass works) \\
Ostrowiec & Iron industry, commerce, services \\
Końskie & Foundry, construction, commerce, hotel industry, transport \\
Kielce & Extraction an processing of mineral resources, food products \\
Włoszczowa & Agriculture, commerce, services, recreation \\
Staszów & Agriculture, commerce, services \\
Pińczów & Agriculture, commerce, services, extractive industry \\
Jędrzejów & Agriculture, agrotourism, ford production and processing \\
Kazimierz & Agriculture, construction, commerce, services \\
\hline Source: Bank Danych Lokalnych, https://bdl.stat.gov.pl/BDL/start (update: 15.09.2019)
\end{tabular}


Przybytniowski J.W., Dziekański P., SYNTHETIC MEASUREMENT USED AS ASSESSMENT OF SPATIAL DISPARITIES OF THE NATURAL ENVIRONMENT, Zeszyty Naukowe Uniwersytetu Przyrodniczo-Humanistycznego w Siedlcach Nr 122, Seria: Administracja i Zarządzanie (49) 2019

Here we can find the Świętokrzyskie Mountains, where there are springs of healing waters and interesting vegetation. The area protected by law is $61.9 \%$ of the total voivodeship area (first position in the country). Here there are areas included in the European ecological network NATURA 2000 (4 areas of special protection of habitats and 2 areas of special protection of birds). Woodland takes a large area of the KieleckoSandomierska upland. It constitutes a base for tourism and agrotourism development. The value of the synthetic measurement allowed us to divide Świętokrzyskie Voivodeship into 4 groups. Among the groups we can observe slight relocation in time and space. In the consecutive years, a high position has been taken by Kielce (1), Starachowice (1), Ostrowiec Św. (1), Krasocin (2). Group A includes units belonging to group $A$ in terms of their development, with the developed industry and located within the impact area of the regional capital. On the other rank-end there is Słupia (Końskie) (2), Smyków (2), Moskorzew (2). These are agricultural County units (Table 2). The indicator is influenced by: the economic character of the unit and the area function (industry, tourism, residential) or the infrastructure (location range). Therefore, the evaluation must include the local character of various structural and functional conditions or the economic structure. The analysis (Table 2) shows that those most strongly affecting the natural environment are group $A$ units, and the least group $D$, assuming the variables related to the human impact on them.

Table 2. Spatial differentiation and synthetic measurement of the natural environment dynamics in the Świętokrzyskie Voivodeship in the years 2009-2015

\begin{tabular}{|c|c|c|c|c|c|c|c|c|c|}
\hline \multirow{2}{*}{ Group } & \multirow{2}{*}{ Municipalities } & \multicolumn{4}{|c|}{$\begin{array}{l}\text { Synthetic measurement } \\
\text { of the natural environemt }\end{array}$} & \multicolumn{4}{|c|}{ Development measurement } \\
\hline & & 2009 & 2012 & 2015 & $2015 / 2009$ & 2009 & 2012 & 2015 & $2015 / 2009$ \\
\hline \multirow{4}{*}{$A$} & Kielce (1) & 0.52 & 0.52 & 0.52 & 0.00 & 0.64 & 0.61 & 0.57 & -0.11 \\
\hline & Starachowice (1) & 0.57 & 0.59 & 0.60 & 0.05 & 0.71 & 0.71 & 0.70 & -0.01 \\
\hline & Ostrowiec Św. (1) & 0.63 & 0.61 & 0.59 & -0.06 & 0.72 & 0.71 & 0.71 & -0.01 \\
\hline & Krasocin (2) & 0.71 & 0.71 & 0.69 & -0.03 & 0.73 & 0.72 & 0.69 & -0.05 \\
\hline \multirow{4}{*}{ B } & Łopuszno (2) & 0.72 & 0.72 & 0.71 & -0.01 & 0.78 & 0.80 & 0.77 & -0.01 \\
\hline & Strawczyn (2) & 0.73 & 0.72 & 0.72 & -0.01 & 0.76 & 0.75 & 0.72 & -0.05 \\
\hline & Chęciny (3) & 0.73 & 0.73 & 0.71 & -0.03 & 0.76 & 0.74 & 0.73 & -0.04 \\
\hline & Secemin (2) & 0.77 & 0.76 & 0.76 & -0.01 & 0.79 & 0.78 & 0.75 & -0.05 \\
\hline \multirow{4}{*}{$\mathrm{C}$} & Górno (2) & 0.78 & 0.77 & 0.76 & -0.03 & 0.79 & 0.78 & 0.76 & -0.04 \\
\hline & Łagów (2) & 0.76 & 0.78 & 0.76 & 0.00 & 0.78 & 0.75 & 0.71 & -0.09 \\
\hline & Masłów (2) & 0.77 & 0.77 & 0.75 & -0.03 & 0.72 & 0.72 & 0.70 & -0.03 \\
\hline & Szydłów (2) & 0.79 & 0.78 & 0.78 & -0.01 & 0.79 & 0.77 & 0.71 & -0.10 \\
\hline \multirow{4}{*}{$\mathrm{D}$} & Sitkówka-Nowiny (2) & 0.80 & 0.79 & 0.78 & -0.03 & 0.57 & 0.57 & 0.58 & 0.02 \\
\hline & Słupia (Konecka) (2) & 0.79 & 0.80 & 0.81 & 0.03 & 0.79 & 0.79 & 0.75 & -0.05 \\
\hline & Smyków (2) & 0.79 & 0.79 & 0.79 & 0.00 & 0.80 & 0.83 & 0.77 & -0.04 \\
\hline & Moskorzew (2) & 0.86 & 0.84 & 0.84 & -0.02 & 0.77 & 0.76 & 0.75 & -0.03 \\
\hline
\end{tabular}

The research results indicated relate to the first stage of research work.

Legend: $O E_{R}$ - synthetic measurement of development; 1 - urban community; 2 - rural community; 3 - urban-rural community; The table includes the 2 best and poorest the community in the group, sorted in accordance to the average of 2009-2015

Source: prepared by the authors on the basis of the data (https://bdl.stat.gov.pl/BDL/start (update: 15.09.2019).

The box plot (Figure 1) shows the highest degree of dispersion of the units in 2015 (in relation to 2014 and 2011) where the data are spread more and assume more varied values. The spread is also shown by longer whiskers and appearing outliers (largely deviating from the box). The group of units deviating from the box, regardless of the studied year or researched area, includes: Starachowice (1), Kielce (1), Ostrowiec Św. (1) (the natural environment measurement), Sandomierz (1), Ożarów (3), Sitkówka-Nowiny (2), Kielce (1), Połaniec (3) (development measurement). 
Przybytniowski J.W., Dziekański P., SYNTHETIC MEASUREMENT USED AS ASSESSMENT OF SPATIAL DISPARITIES OF THE NATURAL ENVIRONMENT, Zeszyty Naukowe Uniwersytetu Przyrodniczo-Humanistycznego w Siedlcach Nr 122, Seria: Administracja i Zarządzanie (49) 2019
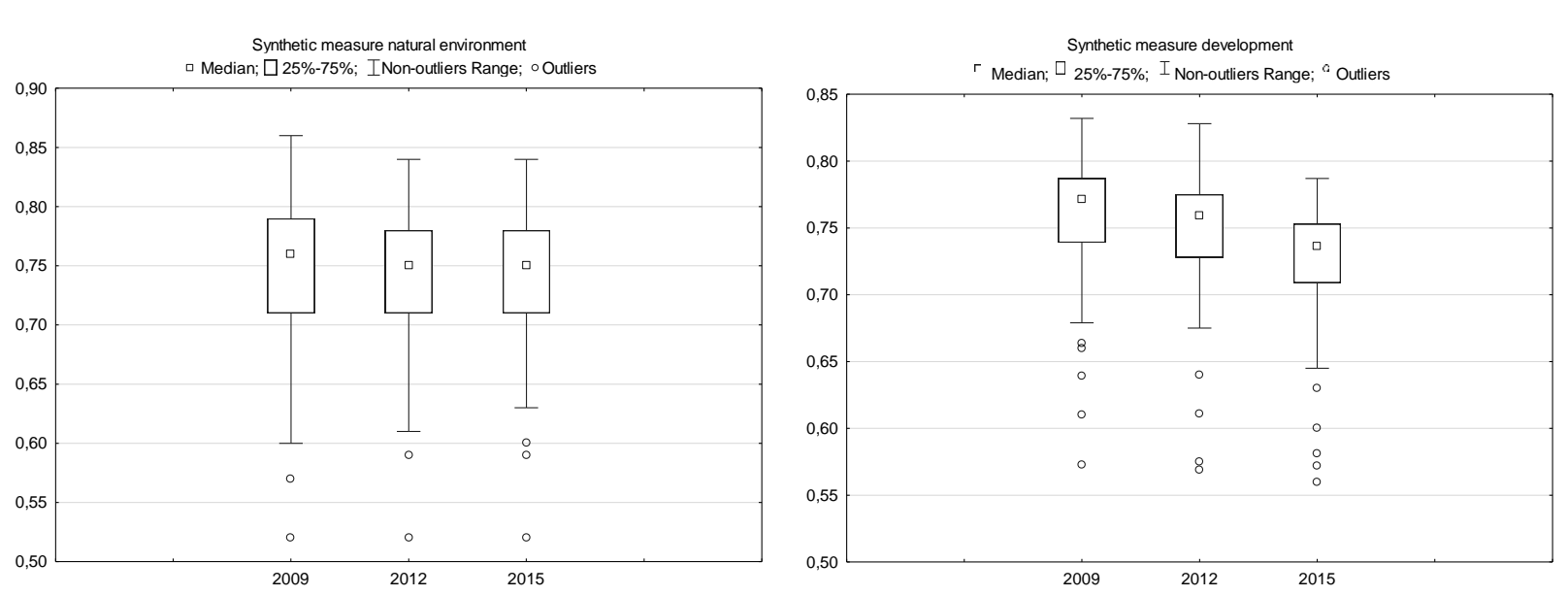

Figure 1. Scatter graph of gimnas of the Świętokrzyskie Voivodeship in the years 2009, 2012 and 2015 Source: prepared by the authors on the basis of the data [https://bdl.stat.gov.pl/BDL/start: (update: 15.09.2019)

Figure 2 shows changes in the synthetic measurement of the natural environment and development in the community of the Świetokrzyskie Voivodeship. Measurement dynamics was similar, which may indicate a similar reaction of units to the changes in the national economy. The analysis indicates a stable condition of the units in the researched area (Pearson's correlation coefficient at
0.975 and 0.979 - the natural environment measurement, slight convergence; 0.866 and 0.892 - convergence, development measurement). Regardless of the measurement, the outstanding units included Kielce (1), Ostrowiec Św. (1), Starachowice (1), Połaniec (3), Ożarów (3) (units of developed industrial function).
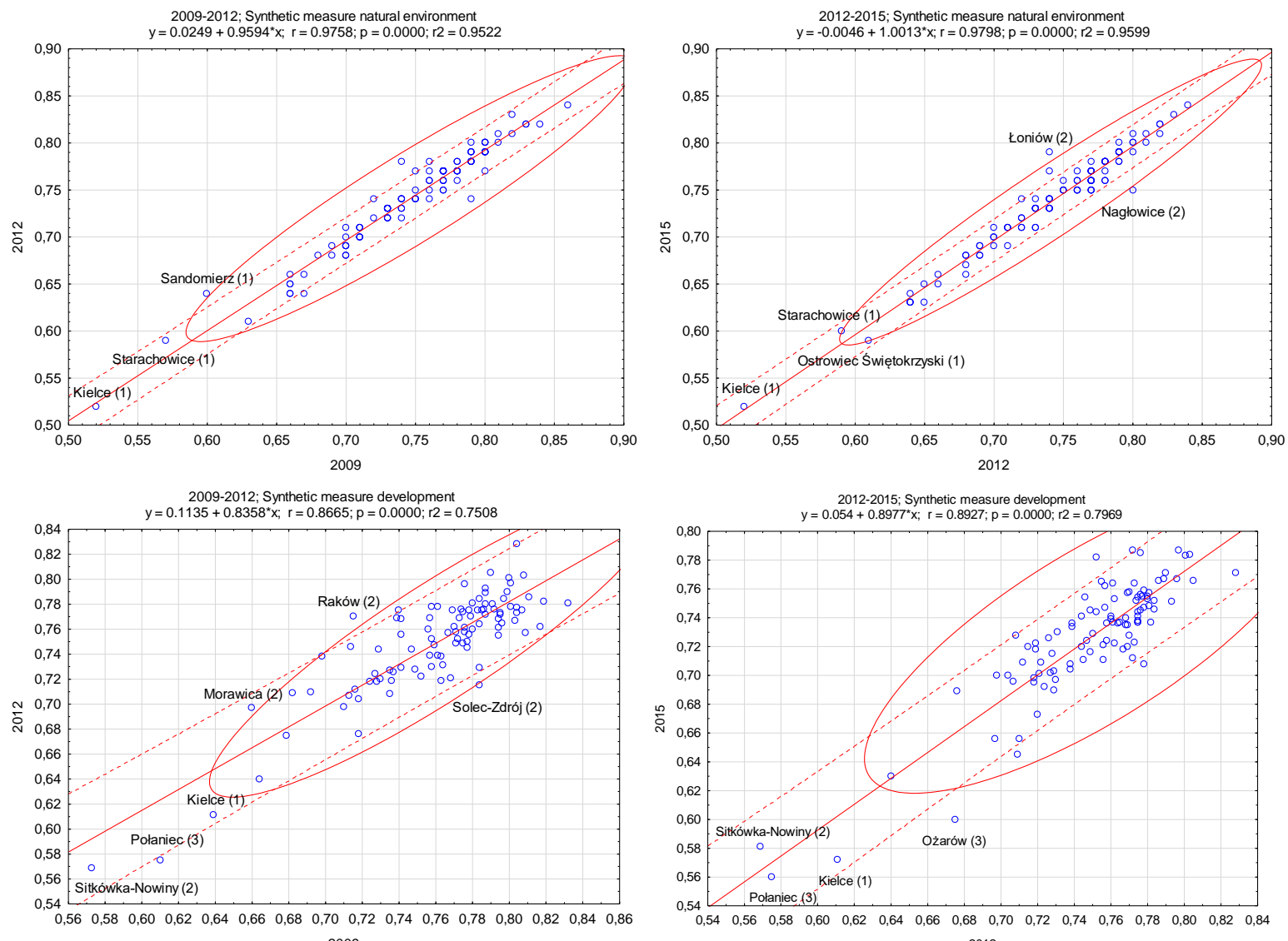

Figure 2. Scatter graph with the best fit of the community of the Swiętokrzyskie Voivodeship in the years 2009, 2012 and 2015

Source: prepared by the authors on the basis of the data [https://bdl.stat.gov.pl/BDL/start: (update: 15.09.2019) 
The analysis of the synthetic measurement of the natural environment in the community of the Świętokrzyskie Voivodeship indicates that in 2015, in relation to 2009, the level of differentiation was stable (standard deviation 0.06-0.06), at a slight reduction of range (0.34-0.32). The coefficient of variation $(0.08-0.08)$ indicates a relatively stable assessment of the natural environment. This measurement indicates that it has been changing in the same way as the natural environment measurement. Standard deviation (0.04-0.04), the level of the classical coefficient of variation (0.060.06 ) indicates a relatively constant measurement of development of the community of the Świętokrzyskie Voivodeship in the studied period 2009-2015.

Table 3. Variation of synthetic measurement of the community of the Świętokrzyskie Voivodeship in the years 2009, 2012 and 2015

\begin{tabular}{lcccccc}
\hline \multirow{2}{*}{ Synthetic measurements } & \multicolumn{3}{c}{ Natural environment measurement } & \multicolumn{3}{c}{ Development measurement } \\
\cline { 2 - 6 } & 2009 & 2012 & 2015 & 2009 & 2012 & 2015 \\
\hline Average & 0.75 & 0.74 & 0.74 & 0.76 & 0.75 & 0.73 \\
Median & 0.76 & 0.75 & 0.75 & 0.77 & 0.76 & 0.74 \\
Standard deviation & 0.06 & 0.06 & 0.06 & 0.04 & 0.04 & 0.04 \\
Variation coefficient & 0.08 & 0.07 & 0.08 & 0.06 & 0.06 & 0.06 \\
Min & 0.52 & 0.52 & 0.52 & 0.57 & 0.57 & 0.56 \\
Max & 0.86 & 0.84 & 0.84 & 0.83 & 0.83 & 0.79 \\
Range & 0.34 & 0.32 & 0.32 & 0.26 & 0.26 & 0.23 \\
Skewness & -1.13 & -1.08 & -1.03 & -1.60 & -1.91 & -1.76 \\
Concentration measurement - kurtosis & 2.35 & 1.81 & 1.49 & 3.61 & 5.48 & 4.26 \\
\hline
\end{tabular}

Source: prepared by the authors on the basis of the data [https://bdl.stat.gov.pl/BDL/start

The data presented in Figure 3 confirm the good fit of linear regression to the real data describing the relationship of synthetic measurement of the natural environment and development of the community of the Świętokrzyskie Voivodeship. Pearson's correlation coefficient was 0.285 in 2009 and 0.330 in 2015.
The units deviating from the studied group were Pawłow (2), Kielce (1), Tuczępy (2), Ożarów (3), Sitkówka-Nowiny (2), Połaniec (3). The indicated units have a strong industrial or agricultural function and are located within the impact area of Kielce, the capital of the region.
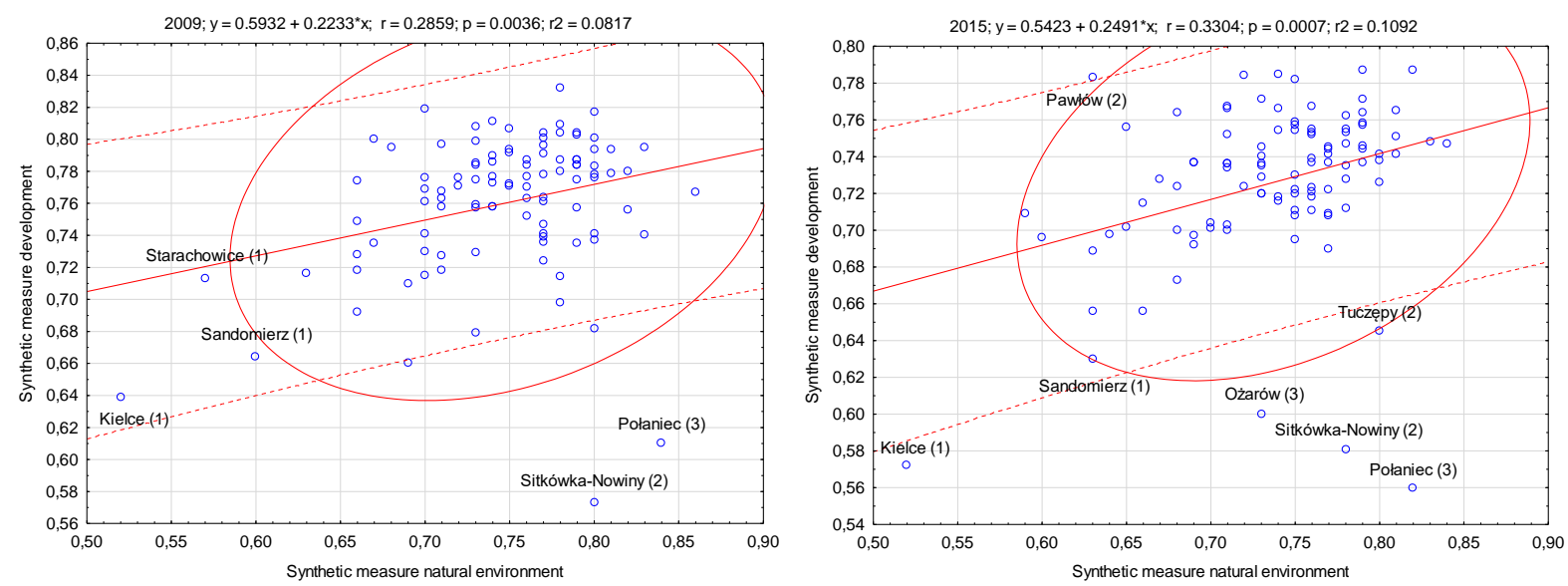

Figure 3. Relation of synthetic measurement of the natural environment and development in the community of the Swiętokrzyskie Voivodeship in 2009 and 2015 Source: prepared by the authors 
Przybytniowski J.W., Dziekański P., SYNTHETIC MEASUREMENT USED AS ASSESSMENT OF SPATIAL DISPARITIES OF THE NATURAL ENVIRONMENT, Zeszyty Naukowe Uniwersytetu Przyrodniczo-Humanistycznego w Siedlcach Nr 122, Seria: Administracja i Zarządzanie (49) 2019

Table 4 presents correlation coefficients between the values of synthetic measurements of the natural environment and development of the community of the Świętokrzyskie Voivodeship. From the presented correlation coefficients we can conclude that spatial variation of development and assessment of the natural environment were fairly stable in the years 2009-2015. The existence of the social and technical infrastructure and the appropriate economic potential have a principal impact on the quality of life of the residents and the development of the regions. For local entities, the infrastructure is the condition for their existence and, also, it may influence an increase in competitiveness. Whereas the development of business activity stimulates the development of infrastructure. The indicated elements in relation to the benefit of location shape the natural environment of the region (Stoła, Luty, 2016; Ferguson, Tamburello, 2015).

Table 4. Correlation of synthetic measurement of assessment of the natural environment and development of the community of the Świetokrzyskie Voivodeship in the years 2009, 2012 and 2015

\begin{tabular}{ccccc}
\hline \multirow{2}{*}{$\mathbf{S}_{\mathbf{i}}$} & \multicolumn{4}{c}{ Correlation coefficient } \\
\cline { 2 - 5 } & gamma & Sperman's & Kendall tau & Pearson's \\
\hline OE $_{S}-\mathrm{OE}_{\mathrm{R}} 2009$ & 0.196 & 0.260 & 0.189 & 0.285 \\
$\mathrm{OE}_{\mathrm{S}}-\mathrm{OE}_{\mathrm{R}} 2012$ & 0.185 & 0.240 & 0.179 & 0.293 \\
$\mathrm{OE}_{\mathrm{S}}-\mathrm{OE}_{\mathrm{R}} 2015$ & 0.262 & 0.342 & 0.253 & 0.330 \\
\hline
\end{tabular}

Legend: OEs synthetic measurement of assessment of the natural environment; OER development measurement Source: prepared by the authors

\section{Conclusion}

On the basis of the research conducted, the authors have drawn the following conclusions:

1. Local development is highly dependent on the undergoing processes in the development centres. The comparison of spatial distribution of a better developed community indicates the growth of a highly developed community around the capital of the region. The centre can grow richer at the expense of peripheral areas (e.g., by attracting human capital (Dziekański, 2017).

2. During the examined period, the level of synthetic environmental measure was affected: the total use of household water per 1 resident $\mathrm{D}$, distribution network per $100 \mathrm{~km}^{2}$ - water pipe system S, distribution network per $100 \mathrm{~km}^{3}$ sewage system $\mathrm{S}$, woodland area $\mathrm{S}$, areas protected by law $\mathrm{S}$, protected monuments $\mathrm{S}$, nature monuments $S$ (as elements dependent on human actions).

3. The activities of a community are of a multidimensional character. The level of development is influenced, by the benefits of location, finance, economic and infrastructure potential, natural resources, etc. Peripheral areas of the voivodeship are characterized by weak development potential. What is characteristic for them is the effect of the outflow of, e.g., human capital, social or economic potential.

4. Low accessibility of statistical data in the community impedes the analysis of actions or programming, conducting and evaluating the development policy of the local self-government.

5. The methods presented enable us to identify the areas of a higher/lower level of efficiency and, next, to programme their support from the public funds within the framework of the regional policy.

\section{References}

Bank Danych Lokalnych https://bdl.stat.gov.pl/ BDL/start

Borys, T. (2013). New directions in the economics of the environment and natural resources in the aspect of the new financial perspective of the European Union, Economics and the Environment 1/44. http://yadda.icm.edu.pl/ yadda/element/bwmeta1.element.agro43fa529b-d22d-4860-816e17ba6c3a032a/c/ 01_borys_tadeusz.pdf (access: 10.12.2019).

Bury, P., Dziekański, P. (2013). Assessment of the financial condition of poviats of the Świętokrzyskie Province in the years 2007-2011 using a synthetic indicator, [in:] Jurcak V., Dziekański P., (ed.), Factors of regional phenomena change, Factors of regional phenomena change, WSBiP in Ostrowiec Świętokrzyski, Ostrowiec Świętokrzyski: 220$-248$. 
Przybytniowski J.W., Dziekański P., SYNTHETIC MEASUREMENT USED AS ASSESSMENT OF SPATIAL DISPARITIES OF THE NATURAL ENVIRONMENT, Zeszyty Naukowe Uniwersytetu Przyrodniczo-Humanistycznego w Siedlcach Nr 122, Seria: Administracja i Zarządzanie (49) 2019

Collins, J.B., Scannell, C.G. (2005). Natural environment data services in distributed modeling and simulation. Net-Centric Approaches to Intelligence and National Security: 149-174.

Dąbrowska, A. (2017). Traditional sectors based on natural resources - a blessing or a curse for less developed regions? A case study of Podlaskie Voivodeship Miscellanea Geographica Regional Studies on Development 21(3): 89-95. DOI: $\quad 10.1515 /$ mgrsd-2017-0020. Open accessible full article: https://content.sciendo. com/view/ journals/mgrsd/21/3/article-p89.xml

Dziekański, P. (2017), Diversification synthetic indicator for evaluating the financial capacity of local government. The case of polish voivodeships, Acta Universitatis Agriculturae Et Silviculturae Mendelianae Brunensis; Volume 65 Number 2.

Dziekański, P. (2015). The natural environment as a factor of regional competitiveness. Modern Management Review, vol. XX, 22 (2/2015): 15-24.

Ferguson, T.W., \& Tamburello, J.A. (2015). The Natural Environment as a Spiritual Resource: $A$ Theory of Regional Variation in Religious Adherence, Sociology of Religion 76 (3): 295314.

Filipowicz, K., Tokarski, T. (2015). Wpływ efektu grawitacyjnego na przestrzenne zróżnicowanie rozwoju ekonomicznego powiatów, Wiadomości Statystyczne nr 5.

Frątczak J. (2001). Environmental awareness of children, adolescents and adults in the aspect of school and non-school education, WSP, Bydgoszcz: https://files2.ngo.pl/files/wspie-ranie. ngo.pl/public/branzaeko.pdf

(access: 10.12.2019).

Ginevičius, R., Gedvilaitè, D., \& Bruzgè, Š. (2015). Assessment of a country's regional economic development on the basis of estimation of a single process (ESP) method. Entrepreneurial Businessand Economics Review, 3(2). doi: 10.15678/EBER.2015. 030210.

Kalfas, D.G., Zagkas, D.T., Raptis, D.I., Zagkas, T.D. (2019). The multifunctionality of the natural environment through the basic ecosystem services in the Florina region, Greece, International Journal of Sustainable Development and World Ecology, 26 (1), pp. 57-68.

Kasztelan A. (2010). Environmental competitiveness of regions - an attempt to conceptualize, Problems Of Sustainable Development 5/2: 77-86, http://ekorozwoj.pol.lublin.pl/no10/h.pdf (access: 09.12.2019).

Kiselitsa, E.P., Shilova, N.N., Liman, I.A., Naumenko, E.E. (2018). Impact of spatial development on sustainable entrepreneurship, Entrepreneurship and Sustainability Issues 6(2): 890-911.

Kotler, P. (2011), Reinventing Marketing to Manage the Environmental Imperative, Journal of Marketing, Vol. 75, No. 4: 132-135.

Kukuła, K. (2014), Regional differences in the degree of environmental pollution in Poland and waste management, Entrepreneurship and Management Vol. 15, vol. 8, part 1 Selected problems of regional development management, Łódź: 183-198.

Mikhaylov, A.S. (2018). Socio-spatial dynamics, networks and modelling of regionalmilieu, Entrepreneurship and Sustainability Issues 5(4): 1020-1030.

Mroczek, K., Tokarski, T. (2014). Gravity effect and technical equipment of work and the diversity of work efficiency in EU countries. Studies in Law and Economics, Vol. XCll.

Pondel, H. Rural area environment - a competitiveness factor or a barrier restricting development? Studies and works of the Faculty of Economic Sciences and Management No. 41, Vol. 2: DOI:10.18276/sip.2015.41: 2-06

Pooler, I. (1987). Measuring Geographical Accessibility: a Review of Current Approaches and Problems in the Use of Population Potentials. Geoforum, vol. 18, no. 3.

Przybytniowski, J.W. (2017). Ecological knowledge as a factor in the increase of awareness and behavior of residents of the Swiętokrzyskie Province; Studies and Materials. Miscellanea Oeconomicae, Faculty of Law, Administration and Management, Jan Kochanowski University in Kielce, vol. II: Kielce, 171-182.

Rook, G.A. (2013). Regulation of the immune system by biodiversity from the natural environment: $A n$ ecosystem service essential to health. Proceedings of the National Academy of Sciences of the United States of America, 110 (46): 18360-18367.

Satoła, Ł., Luty, L. (2016). The level of equipment with municipal infrastructure and the financial situation of municipalities. Quantitative methods in economic research, T. XVII, Notebook. 2: 101-110.

Selivanova-Fyodorova, N., Komarova, V., Lonska, J, Mietule, I. (2019). Differentiation of internal regions in the $E U$ countries. Insights into Regional Development, 1(4): 370-384.

Sonow al, C.J. (2009). Environmental education in schools: the Indian scenario. Journal of Human Ecology, 28(1): 15-36.

Stanny, M. (2012). Level of social and economic development in Poland - measurement for a complex phenomenon. Retrieved form http://admin.www. irwir-pan.waw.pl/dir_upload/ site/files/Monika/PomiarZjawiskaZlozonego_IR WIR20 12.pdf (15.09.2019). 
Strong, K.C. (1996). A postmodern feminist perspective on organizations in the natural environment: Rethinking ecological awareness, Business and Society, 35 (1): 62-78.

Tokarski, T. (2005). Statistical analysis of the regional differentiation in labor productivity, employment and unemployment in Poland, Publisher of the Polish Economic Society, Warsaw: 207.

Trojak, M., Tokarski, T. (ed.) (2013), Statistical analysis of spatial diversity of economic and social development of Poland, ed. UJ, Krakow.

Toruński, J. (2012). The impact of environmental management in the commune on its development Scientific. Notebooks of the Humanistics anad Natural University in Siedlcy No. 94 Series: Administration and Management, Siedlce.
Ward, J.H. Jr. (1963). Hierarchical grouping to optimize an objective function. Journal of the American Statistical Association: 58.

Wysocki, F. (1996). Methods of multivariate statistical analysis in recognizing types of agricultural spatial structure, Annals of AR in Poznań, series: Scientific Dissertations, Notebook. 266, Poznan. 